\title{
Developing Students' Reading Comprehension Skill through Reciprocal Teaching Strategy
}

\author{
Diana Oktavia and Dina Fitriana \\ Universitas Pendidikan Indonesia \\ STKIP Pasundan \\ diannaoktav@gmail.com
}

\begin{abstract}
Using strategy is beneficial to make reading easier, more effective, and more comprehensible. Dealing with the notion that students must be independent in reading brings up the inquiry of what strategy helps to develop reading comprehension skill. Through a quasi-experimental study involving test before and after intervention, the study was aimed to find out the effectiveness of reciprocal teaching strategy on developing students' reading comprehension skill. The results revealed that students were interested in using reciprocal teaching strategy, and their achievements in reading comprehension also improved significantly. In conclusion, the study shows that reciprocal teaching strategy is effective to develop students' reading comprehension skill, as proven by significant difference in the result between the experimental and the control groups $\left(t_{o}=3.78>t\right.$-table $=$ 2.000). The study has implications for both teachers and students to enrich the strategy and media in teaching and learning reading comprehension effectively.
\end{abstract}

Keywords: reading skill; reciprocal teaching strategy; strategy of learning reading comprehension

\section{INTRODUCTION}

Reading is the processes by which the meaning of a written text is understood (Richards \& Schmidt (2010, p.483). The processes include discovering meaning from written textin a social atmosphere through bottom-up (textdriven) processing and top-down (conceptually-driven) processing using strategies and skills (Gebhard, 2006, p. 194). Reading comprehension is the process of extracting and constructing meaning together through interaction and involvement with written language (Snow, 2002, p. 11). Reading is still the most important skill as general language ability's assessments are created, it is arguably the most essential skill to get success in all educational contexts (Brown, 2004, p. 185).

A strategy is the purposeful actions used before, during, or after reading a text to improve reading comprehension. Comprehension strategies help readers to improve understanding, overcome difficulties, and counterbalance knowledge related to the text. In order to be able to use reading strategies effectively, teacher should help students learn to use comprehension strategies independently by releasing responsibility little by little. There are specific strategies taught individually or in combination with other effective comprehension strategies which are able to improve comprehension (Shanahan et al, 2010, p. 10).

The question of how to develop students' reading comprehension skill is an issue to the needs of reading skill. In a technologically sophisticated society, drill-andpractice instructional models are insufficient as students must be independent in constructing meaning from text. Therefore, the instructional actions must be more flexible, interactive, and problem-focused (Pearson, Rochler, Dole, \& Duffy, 1990, p. 15). Using strategy is beneficial to make reading easier, more effective, and more comprehensible. Dealing with the notion that students must be independent in reading brings up the inquiry of what strategy helps to develop reading comprehension skill. In order to overcome those matters, teachers should look for strategies in teaching and developing students' reading comprehension skill.

Experts introduce various ways of developing reading skills, one of them is reciprocal teaching strategy. According to Palincsar and Brown (1984, p. 124), reciprocal teaching is "a procedure where teacher and student take turns leading a dialogue concerning sections of a text". The steps of reciprocal teaching strategy are predicting, questioning, clarifying, and summarizing. Reciprocal teaching strategy can improve the quality of summarizing, questioning, clarifying, improve standardized comprehension scores, etc. (Palincsar and Brown, 1984, p. 117).

Reciprocal teaching strategy has many advantages in teaching learning reading. Those advantages are; improving students' ability in finding the important ideas, developing ideas and questions, and also in summarizing the information. Reciprocal teaching strategy can improve students reading comprehension as Palincsar and Brown (1984:117) stated that, "Reciprocal teaching ... led to sizable gains on criterion tests of comprehension, reliable maintenance over time, generalization to classroom comprehension tests, transfer to novel tasks that tapped the trained skills of summarizing, questioning, and clarifying, and improvement in standardized comprehension scores."

In order to implement teaching reading comprehension by using reciprocal teaching strategy in the classroom, there are several things to do as the procedure as stated by Palincsar (n.d., p. 6). First, the students are introduced to reasons and importance of using reading 
strategies. Then, the overall description and also illustration of the procedure of reading strategies are explained to the students. After that, the students practice each of the reciprocal teaching strategies.

Many studies have ever investigated the effects of using reciprocal teaching strategy in developing students' reading comprehension. A study conducted by Sarasti (2007) found that reciprocal teaching was an effective intervention in increasing students' reading comprehension skills as they showed continuous development on the daily comprehension. Another study conducted by DiLorenzo (2010) showed that the intervention of reciprocal teaching improved each student group's science comprehension overall, and that after the intervention of reciprocal teaching removed, the improvements lasted for the individual student groupings although it was not found overall. A review of some studies about reciprocal teaching conducted by Rosenshine and Meister (1993) stated that reciprocal teaching, provided by explicit teaching in advance, gave significant results due to its successful for all types of students. Seven of eight studies reviewed brought about significant result on at least one dependent measure when explicit teaching used.

The study conducted a quasi-experimental study because it was aimed to find out the effectiveness of one of reading strategy, which is reciprocal teaching strategy, in developing students' reading comprehension skill. The study focused on reciprocal teaching strategy on developing reading comprehension skill of the first grade students of a senior high school in Bandung. It could give contribution to the notion of how to develop students' reading comprehension skill in an effective way that raise the students' interest and improve their skills. As the strategy was introduced to the students, it would also add strategy choices for their own learning. In line with that, the problem statements discussed in this study were as follows.

1. Does reciprocal teaching strategy have significant better result than the conventional method in developing students' reading comprehension skill?

2. Is reciprocal teaching strategy effective in developing students' reading comprehension skill?

\section{Reading Comprehension}

\section{THEORETICAL FRAMEWORKS}

Reading comprehension according to Snow (2002) is the process of extracting and constructing meaning together through interaction and involvement with written language. The words extracting and constructing are used to emphasize both the importance and the insufficiency of the text as a determinant of reading comprehension. She also added that comprehension entails three elements, those are the reader who is doing the comprehending; the text that is to be comprehended; and the activity in which comprehension is a part. Reading comprehension is the process of constructing meaning by coordinating a number of complex processes that includes word reading, word and world knowledge, and fluency. (Klingner et al., 2007, p. 2). When we read, we include all the capacities, abilities, knowledge, and experiences that a person brings to the act of reading. According to U.S. Department of Education (2008), "Comprehension strategies are routines and procedures that readers use to help them make sense of texts". For example, active readers may think about what they already know about a specific topic after they read the title of a magazine article. They may predict what the article will be about. They may visualize parts of the text. They may summarize the main points as they are reading. They may ask questions as they read. They are aware when the text is making sense and when it is confusing or unclear.

\section{Comprehension Strategies}

Comprehension strategies can be taught in two ways, those are individually and in combination. Specific strategies that can be taught individually are strategies that are introduced individually by practicing it for some period of time. Those specific strategies explained by Shanahan et al. (2010) are; activating prior knowledge or predicting, students think about what they already know and use that knowledge in conjunction with other clues to construct meaning from what they read-they will also check their predictions by continue reading; questioning, students develop and attempt to answer questions about the important ideas in the text while reading, using words such as where or why to develop their questions; visualization, students develop a mental image of what is described in the text; monitoring, clarifying, or fix-up, students pay attention to whether they understand what they are reading, and when they do not, they reread or use strategies that will help them understand what they have read; drawing inferences, students generate information that is important to constructing meaning but that is missing from, or not explicitly stated in, the text; and summarizing or retelling, students briefly describe, orally or in writing, the main points of what they read.

Apart from individually strategies, specific strategies can be taught in combination (multiple-strategy) as introduced at the same time and practiced in combination so that readers learn to use them together as they read (Shanahan et al., 2010, p. 13). Those specific strategies are reciprocal teaching, a take turns leading conversation on the text using four strategies (predicting, clarifying, questioning, summarizing) modelled by the teacher; transactional strategy instruction, focus on a few strategies at a time, concentrating on improving the students' memory, comprehension, and problem-solving skills. The teacher selects from a large menu of strategies to explicitly teach; informed strategies for learning, combine a variety of reading comprehension strategies to show students that the strategies they learn are useful and necessary for being able to read with understanding. When combining strategies, teachers can display a bulletin board linking each strategy to a picture or themed metaphor representing how to put each into practice; and concept-oriented reading 
instruction, teach comprehension strategies in the context of learning about an overarching concept, typically in the natural sciences, in order to engage students and motivate them to learn.

\section{Reciprocal Teaching Strategy}

Reciprocal Teaching was first introduced in the early 1980's by Ann Brown and Annemarie Sullivan Palincsar. According to Brown and Palincsar (1985, p. 2) reciprocal teaching is an instructional method in which an adult teacher and a group of students take turns leading a dialogue aimed at revealing the meaning of the text. In this strategy, the teacher describes all of the strategies in succession and then models each strategy in turn and explains why the strategy helps students understand the text (Shanahan et al., 2010, p. 14).

The ultimate goal of reciprocal teaching is to influence how students interact with the text. It aims to design instruction that really works in the practical sense of helping students to improve performance of a particular task and to take charge of learning in the future (Brown and Palincsar, 1985, p. 4).

Reciprocal teaching strategy has many advantages in teaching learning reading. Those are improving students' ability in finding the important ideas, developing ideas and questions, and also in summarizing the information. Reciprocal teaching strategy can improve students reading comprehension as Palincsar and Brown (1984, p. 117) stated that, "Reciprocal teaching ... led to sizable gains on criterion tests of comprehension, reliable maintenance over time, generalization to classroom comprehension tests, transfer to novel tasks that tapped the trained skills of summarizing, questioning, and clarifying, and improvement in standardized comprehension scores."

\section{Strategies in Reciprocal Teaching}

There are four strategies used in reciprocal teaching as steps to get the meaning of the reading. These four activities provide a dual function, that of enhancing comprehension and at the same time affording an opportunity for the student to check whether it is occurring. That is, they can be both comprehension-fostering and comprehension-monitoring activities if properly used (Palincsar and Brown, 1984, p. 121).

Predicting was attempted if the students or teachers recognized any cues that served to herald forthcoming material (Brown and Palincsar, 1985, p. 16). When students make predictions, they hypothesize what the author will discuss next. They must activate the relevant background knowledge they already possess as predicting gives the students a purpose for reading either to prove or disprove their hypotheses. Additionally, it gives students the opportunity to link the new knowledge they will encounter in the text with the knowledge they already possess (Bottomley \& Osborn, 1993, p. 3). The predicting strategy also encourages the use of text structure. Students learn that headings, subheadings, and questions embedded in the text are useful means of anticipating what might occur next.

Questioning, according to Brown and Palincsar (1985, p. 16), was not practiced as an isolated activity, but as a continued goal of the whole enterprise. Questioning gives students the opportunity to identify the kind of information that provides the substance of a good question, to form the question, and then to engage in self-testing. Students become much more involved in the reading activity and in the text when they are posing and answering questions themselves and not merely responding to teacher or text questions (Bottomley \& Osborn, 1993, p. 3).

Clarifying is particularly important to students who have a history of comprehension difficulty. Such students can make a habit of not understanding what they read. These students very likely believe that the purpose of reading a passage is to say the words correctly; they may not be particularly uncomfortable with the fact that the words, and, indeed, the passage, are not making much sense (Bottomley \& Osborn, 1993, p. 4). When students are asked to clarify, their attention is called to the fact that there may be many reasons why the text is difficult to understand (e.g., unfamiliar vocabulary, unclear referent words, new concepts).They learn to be alert to the effects of such impediments on comprehension and to take the necessary steps to restore meaning (e.g., reread, ask for help). Clarifying occurred only if there were confusions, whether in the text (unclear referent, etc.) or in the student's interpretation of the text.

Summarizing is a means for integrating the information presented in the text. As the students proceed through the passage, the teacher guides them in integrating the content across paragraphs and sections of the passage (Bottomley \& Osborn, 1993, p. 4). Summarizing was modelled as an activity of self-review, a means of determining that the content had been understood (Brown and Palincsar, 1985, p. 15).

\section{Teacher's Role in Reciprocal Teaching}

The teacher's role in practicing reciprocal teaching with the students is described by Brown and Palincsar (1985, p. 18). The teacher's role is to model the activities and to engage the students at a level judged to be within their grasp at any moment in time. As student masters one level of involvement, the teacher increases her demands so that the students are gradually called upon to adopt the expert role more fully and independently. The teacher then fades into the background as the students take charge of their own learning from texts.

\section{Procedure of using Reciprocal Teaching Strategy}

In order to implement teaching reading comprehension by using reciprocal teaching strategy in the classroom, there are several things to do as the procedure as stated by Palincsar (n.d., p. 6).

First, the students will be divided into groups of four and be asked to pick one card given to the groups. Then, 
the tasks for each different card and how each task should be done (in sections or in each paragraph) will be explained. The procedure of this strategy emphasizes the form of dialogue or discussion about the text and that everyone takes a turn assuming the role of teacher in discussion.

The students will be asked to just read the title and picture of a given text. Based on the title and picture seen, an example of prediction will be given, then the predictors will be asked whether they have any prediction or not. The questioners, clarifiers, and summarizers will be also treated same as the predictors. After they get what they can predict, ask, clarify, and summarize, they will be asked to write it on their notes. The activities continue to each paragraph by being given guidance. Then they then will be asked to check and discuss whether their predictions, clarifications, and summaries are true or not and whether their questions can be answered in the text or not. Finally, they will be asked to share their discussion result with the others and answer the questions of the text together. When the students understand, they will be asked to lead their own groups to help another understand and to take turn as well. The students then will be asked to practice the role on new texts led by their own group.

\section{METHODS}

This study used quasi-experimental design with nonequivalent (pre-test and post-test) control-group design. It was chosen due to the aim of quasi-experimental design was to "deliberately control and manipulate the conditions which determine the events in which they are interested, introduce an intervention and measure the difference that it makes" (Cohen, Manion, \& Morrison, 2007, p. 272). It is in line with this study's aim which was to find out the effects of reciprocal teaching strategy on developing students' reading comprehension skill. The study concerned on reciprocal teaching strategy and reading comprehension skill.

In conducting the study, there were a few steps taken as the procedure. First, the students were divided into two groups, which were experimental group and control group. Second, research instruments were prepared to test the students' ability in reading comprehension. The research instruments were in multiple choice forms consisted of a few text types. Third, pre-test was executed in the first meeting in order to make sure that there was no significant difference in the students' score between experimental group and control group. Fourth, lesson plans for treatments were organized and implemented. Between the implementation of pretest and post-test, intervention was conducted. The intervention in form of treatment was given four times with different topics. Four texts used on the treatments were 130 Cars in Foggy UK Pileup (Sudarwati \& Grace, 2014), Borobudur Temple (Sundayana, Marsongko, Sofyanda, Kurnia, \& Hartati, 2004), Private Conversation (Zumakhsin \& Mufarichah, 2007), and The Phone is Off (Sundayana et al., 2004).
These treatments were conducted to know the effectiveness of using reciprocal teaching strategy in developing the students' reading comprehension skill. The students in the experimental group is given treatment, while the students in the control group was not given any treatment so they just do silent reading and answer questions as usual steps in learning reading comprehension. Fifth, post-test was executed in the last meeting to find out the result of the treatment. And last, the data collected were analysed and interpreted to get the conclusions.

In giving the treatment, the students first were divided into groups of four and each student chose one reciprocal reading role card given to the groups. The tasks of each role written on the cards and how each task should be done (in sections or in each paragraph) were described, given examples, and then the students asked to implement the tasks by guidance. The procedure of this strategy emphasizes the form of discussion about the text and that everyone took a turn assuming the role of teacher in discussion. Next, the students were asked to read a section of a given text. Based on the section read, an example of prediction is given, then the predictors were asked whether they have any prediction or not. The questioners, clarifiers, and summarizers were also treated same as the predictors. After they got what they could predict, ask, clarify, and summarize, they were asked to write it on their notes. The activities continued to other sections by being guided. Then they were asked to check and discuss whether their predictions, clarifications, and summaries were true or not and whether their questions could be answered in the text or not. Finally, they were asked to share their discussion result with the others and answer the questions of the text together. When the students understood, they were asked to lead their own groups to help other understand and to take turn as well. The students then asked to practice the role on new texts led by their own group.

The participants of the study were the first grade students of a senior high schools in Bandung. There were 86 participants randomly chosen from the population attached to two classes as the experimental group and the control group.

In collecting the data, the instruments of this study were pre-test and post-test. As Sugiyono (2010, p. 148) says, “.... Instrumen penelitian adalah suatu alat yang digunakan untuk mengukur fenomena alam mau pun sosial yang diamati." Pre-test on the study was used to measure students' reading comprehension skill before the intervention. It was intended to make sure that the two groups were not significantly different on their reading comprehension skill before the intervention implemented. Post-test was conducted to know whether or not there was development in the scores of the students after given intervention. It was also conducted to know whether reciprocal teaching strategy was effective in developing students' reading comprehension skill or not. The texts used in the pre-test and post-test were taken from available books for the appropriate grade of senior high school. The 
question items used in the pre-test and post-test were in multiple choice form consisting of 25 items covering the steps of reciprocal teaching strategy (predicting, questioning, clarifying, summarizing).

The data taken from pre-test and post-test of experimental group and control group were analysed using $t$ test for independent groups (Coolidge, 2000, p. 144). The pre-test scores of experimental group and control group were analysed and interpreted. Then the post-test scores of experimental group and control group were also analysed, interpreted, and conclusions were drawn.

\section{RESULTS AND DISCUSSION}

The pre-test scores of reading comprehension conducted on the first meeting were analyzed by using $t$ test formula for independent groups. The pre-test computation revealed that the derived $t$ value $\left(t_{o}\right)$ was 1.28 , while the critical $t$ value ( $t$-table) with the $d f=84$ at $p=.05$ of two-tailed was 2.000. It showed that the value of the derived $t\left(t_{o}\right)$ was smaller than that of the critical $t$ ( $t$ table), $1.28<2.000$. This means there was no significant difference in the mean scores between the students of experimental group and control group before the treatment of reciprocal teaching strategy conducted. Thus, the treatment by using reciprocal teaching strategy started from similar level of students' skill in reading comprehension both in the experimental group and in the control group.

The post-test scores of reading comprehension were also analyzed by using $t$ test formula for independent groups. The post-test computation revealed that the derived $t$ value $\left(t_{o}\right)$ is 3.78 , while the critical $t$ value ( $t$-table) with the $d f=84$ at $p=.05$ of two-tailed was 2.000. It shows that the value of the derived $t\left(t_{o}\right)$ was bigger than that of the critical $t$ (t-table), $3.78>2.000$. This means that that there was significant difference in the result between using reciprocal teaching strategy and the conventional method in developing reading comprehension skill to the students of a senior high school in Bandung.

The main objective of this study was to investigate whether or not using reciprocal teaching strategy in developing students' reading comprehension has significant difference in the result between the experimental group and the control group. The findings showed that there was a significant difference in the result between using reciprocal teaching strategy and the conventional method in developing students' reading comprehension. This study also was aimed to figure out whether or not using reciprocal teaching strategy is effective in developing studentsreading comprehension. From the findings of post-test scores computation above, it also implied that reciprocal teaching strategy is effective based on its results. The results of this study were in line with the results of previous studies conducted by Sarasti (2007); DiLorenzo (2010); and Rosenshine and Meister (1993).

\section{CONCLUSION}

This study answered the intended objectives. First, reciprocal teaching strategy had significant better result than the conventional method in developing students' reading comprehension skill. And second, reciprocal teaching strategy was effective to develop students' reading comprehension skill. The answers were gained by interpreting the computation results of pre-test and posttest scores. This study is expected to give contribution to the teacher, students, and all the reader, especially in enriching effective strategies to develop reading comprehension skill. In addition, it is recommended for other researchers to use various media in implementing the strategy in order to make students interested and enrich their knowledge of various ways in developing reading comprehension skill. As this study was conducted in one of senior high school in Bandung, it is better for other researchers intending to do similar research to choose another school in order to get various results and also introduce and make better use of the strategy in various schools.

\section{REFERENCES}

Bottomley, D., \& Osborn, J. (1993). Implementing reciprocal teaching with fourth-and fifth-grade students in content area reading. Retrieved on September $\quad 10, \quad 2015 \quad$ from http://hdl.handle.net/2142/17937

Brown, A. L., \& Palincsar, A. S. (1985). Reciprocal teaching of comprehension strategies: A natural history of one program for enhancing learning. Cambridge: Bolt Beranek and Newman Inc.

Brown, H.D. (2004). Language assessment: Principles and classroom practices. New York, NY: Longman.

Cohen, L., Manion, L., \& Morrison, K. (2007). Research methods in education (6th ed.). New York, NY: Routledge.

Coolidge, F. L. (2000). Statistics: A gentle introduction. London: SAGE Publications.

DiLorenzo K. E. (2010). The effects of reciprocal teaching on the science literacy of intermediate elementary students in inclusive science classes. Doctoral dissertation, Florida Atlantic University.

Gebhard, J. G. (2006). Teaching English as a foreign or second language: A teacher self-development and methodology guide (2nd ed.). Ann Arbor: University of Michigan.

Klingner, J. K., Vaughn, S., \& Boardman, A. (2007). Teaching reading comprehension to students with learning difficulties. In K. R. Harris, \& S. Graham (Eds.), What works for special-needs learners. New York: The Guilford Press.

Palincsar, A. S. (n.d.). Reciprocal teaching. Teaching/Learning Strategies, 5-10. Retrieved from http://www.psy.cmu.edu/ siegler/418-Palinscar.pdf

Palincsar, A. S., \& Brown, A. L. (1984). Reciprocal teaching of comprehension-fostering and 
comprehension-monitoring activities. Cognition and Instruction, I(2), 117-175. Retrieved on July 27, 2015 from

http://eclass.uoa.gr/modules/document/file.php/PHS1 $22 / \% \mathrm{CE} \% 91 \% \mathrm{CF} \% 81 \% \mathrm{CE} \% \mathrm{~B} 8 \% \mathrm{CF} \% 81 \% \mathrm{CE} \% \mathrm{~B} 1 /$ Reciprocal\%20teaching.pdf

Pearson, P. D., Rochler, L. R., Dole, J.A., \& Duffy, G. G. (1990). Developing expertise in reading comprehension: What should be taught? How should it be taught? Illinois: University of Illinois at UrbanaChampaign.

Richards, J. C., \& Schmidt, R. (2010). Longman: Dictionary of language teaching \& applied linguistics (4th ed.). Harlow: Pearson Education Limited.

Rosenshine, B., \& Meister, C. E. (1993). Reciprocal teaching: A review of 19 experimental studies. Retrieved on September 10, 2015 from http://hdl. handle.net/2142/17744

Sarasti, I. A. (2007). The effects of reciprocal teaching comprehension-monitoring strategy on $3^{\text {rd }}$ grade students' reading comprehension. Doctoral dissertation, University of North Texas.

Shanahan, T., Callison, K., Carriere, C., Duke, N. K., Pearson, P. D., Schatschneider, C., \& Torgesen, J. (2010). Improving reading comprehension in kindergarten through 3rd grade: IES practice guide. NCEE 2010-4038. What Works Clearinghouse. Retrieved on August 23, 2015 from whatworks.ed.gov/publications/practiceguides

Snow, C. E. (2002). Reading for understanding: Toward an $R \& D$ program in reading comprehension. Santa Monica: RAND.

Sudarwati, T. M., \& Grace, E. (2014). Pathway to English for senior high school and MA grade X: Program peminatan. Jakarta: Erlangga.

Sugiyono. (2010). Metode penelitian pendidikan: Pendekatan kuantitatif, kualitatif, dan $R \& D$. Bandung: Alfabeta.

Sundayana, W., Marsongko, E., Sofyanda, A., Kurnia, R., \& Hartati, A. (2004). Contextual learning: Developing competencies in English use for SMA kelas II semester 1. Bandung: Grafindo Media Pratama.

U.S. Department of Education. (2008). Direct, explicit comprehension strategy instruction. Retrieved on August 28, 2015 from http://www.adlit.org/ article/27740/

Zumakhsin, Mufarichah, Y. (2007). Progress: A contextual approach to learning English for senior high school IPA \& IPS program grade XI. Jakarta: Ganeca Exact. 